\title{
Algoriphagus aquaeductus sp. nov., isolated from a freshwater pipe
}

Correspondence

Jan Erik Rau

jerau@uni-bremen.de

\author{
Jan Erik Rau, Karl-Heinz Blotevogel and Ulrich Fischer
}

Zentrum für Umweltforschung und nachhaltige Technologien, Fachbereich Biologie/Chemie, Abteilung Marine Mikrobiologie, Universität Bremen, Leobenerstraße, D-28359 Bremen, Germany
A Gram-staining-negative, aerobic to microaerophilic, rod-shaped, red-coloured bacterium, strain $\mathrm{T}^{\top}{ }^{\mathrm{T}}$, was isolated from a freshwater pipe on Tenerife island. A polyphasic taxonomic study was performed in order to characterize the strain in detail. The isolate is surrounded by a slime capsule, occurs singly, in the form of short chains, or in aggregates, and exhibits catalase and oxidase activities. Growth was observed at $15-42{ }^{\circ} \mathrm{C}$. Optimum growth occurred at $\mathrm{pH} 8$ with mono- and disaccharides, followed by polysaccharides and deoxysaccharides, but the bacterium utilized only a restricted spectrum of alcohols, alditols, amides, amines, carboxylic acids and amino acids. Strain $\mathrm{T}^{\top}$ tolerated concentrations of $0-4 \%(\mathrm{w} / \mathrm{v}) \mathrm{NaCl}$ and contained $\mathrm{MK}-7$ as predominant isoprenoid quinone as well as carotenoids, but lacked pigments of the flexirubin type.

The predominant fatty acids were iso- $C_{15: 0}(32.2 \%)$, summed feature $3\left(C_{16: 1} \omega 6 c\right.$ and/or $\left.\mathrm{C}_{16: 1} \omega 7 c ; 22.5 \%\right)$, and iso- $\mathrm{C}_{17: 0} 3-\mathrm{OH}(7.9 \%)$. Major polar lipids were phosphatidylethanolamine, phospholipids, aminophospholipids and other lipids of unknown character. The DNA G $+\mathrm{C}$ content was approximately $41.8 \mathrm{~mol} \%$. The sequence of the 16S-rRNA gene assigned strain $\mathrm{T} 4^{\top}$ to the CFB group, forming a coherent cluster with species of the genus Algoriphagus with the highest similarity of $98.8 \%$ to Algoriphagus aquatilis $A 8-7^{\top}$. DNA-DNA hybridization revealed $37.5 \%$ relatedness to strain $A 8-7^{\top}$. Based on morphological, physiological and molecular properties as well as on phylogenetic distinctiveness, strain $\mathrm{T} 4^{\mathrm{T}}$ should be placed into the genus Algoriphagus as a novel species, for which the name

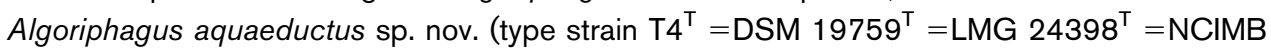
$14399^{\top}$ ) is proposed.
Isolation of strain $\mathrm{T} 4^{\mathrm{T}}$ was performed from water samples taken from a freshwater pipe on Tenerife island, Spain. Aliquots of these samples were streaked on half-strength nutrient agar $(\mathrm{NA} / 2)$ plates, $\mathrm{pH} 8$, and incubated at $30{ }^{\circ} \mathrm{C}$. $\mathrm{NA} / 2$ medium contained $\left(\mathrm{l}^{-1}\right.$ distilled water) $2.5 \mathrm{~g}$ peptone, $1.5 \mathrm{~g}$ beef extract and $15.0 \mathrm{~g}$ agar. Repeated transfers were made until a pure culture of strain $\mathrm{T} 4^{\mathrm{T}}$ was obtained. Strain $\mathrm{T} 4{ }^{\mathrm{T}}$ was cultivated routinely at $30{ }^{\circ} \mathrm{C}$ for $2-7$ days on either solid NA/2 or mineral salt medium (MSM) supplemented with $20.0 \mathrm{~g}$ beef extract $\mathrm{l}^{-1}$ (BD Diagnostic Systems) $\left(\mathrm{MSM}^{+}\right)$, both adjusted to $\mathrm{pH} 8$, or in liquid NA/2 or $\mathrm{MSM}^{+}$by shaking at 200 r.p.m. Strain $\mathrm{T}^{\mathrm{T}}$ cannot grow satisfactorily in marine 2216 medium (Difco). MSM, vitamin solution and trace element solution were prepared as described by Bast (2001). Culture conditions were modified by varying the temperature $\left(5-45{ }^{\circ} \mathrm{C}\right)$, salinity $(0-15 \%, w / v)$ or $\mathrm{pH}(5-10)$, respectively. $\mathrm{pH}$ adjustment of

Abbreviation: DDH, DNA-DNA hybridization.

The GenBank/EMBL/DDBJ accession number for the 16S rRNA gene sequence of strain $\mathrm{T} 4^{\mathrm{T}}$ is EU161637.

Two supplementary figures, two tables and two text files are available with the online version of this paper. the $\mathrm{MSM}^{+}$medium was done with the appropriate biological buffers. To avoid alkalinization of this medium, the normal $\mathrm{NH}_{4} \mathrm{Cl}$ concentration of $1.0 \mathrm{~g} \mathrm{l}^{-1}$ was lowered to only $1 / 10$. Growth under anaerobic conditions was determined in MSM, supplemented with either only $5 \mathrm{mM}$ glucose or $5 \mathrm{mM}$ glucose and $10 \mathrm{mM}$ nitrate. Both media were prepared anaerobically under nitrogen atmosphere.

Colony morphology was determined on $\mathrm{MSM}^{+}$agar plates by stereo microscopy (Carl Zeiss Stemi SV 6). Gliding motility was observed at the edge of the colonies by direct microscopy (Carl Zeiss Axiolab). Cell morphology and motility were examined by phase-contrast microscopy (Carl Zeiss Axiolab) and transmission electron microscopy (Carl Zeiss EM 10 A). Ruthenium red was used for staining of a slime layer (Pate \& Ordal, 1967). Gram reaction was determined by using the Merck Gram staining kit according to the manufacturer's instructions. The presence of catalase and cytochrome oxidase was determined as described by Süßmuth et al. (1987) and by using Merck Bactident oxidase test strips according to the manufacturer's instructions, respectively. The tests were performed after 3-4 days of incubation. Acid production from carbohydrates was 
Table 1. Differential phenotypic characteristics of strain $T 4^{\top}$ and closely related species of the genus Algoriphagus including Algoriphagus ratkowskyi $\mathrm{IC} 025^{\top}$, the type species of the genus

Strains: 1, Algoriphagus aquaeductus sp. nov. T4 $4^{\mathrm{T}} ; 2$, A. alkaliphilus AC-74 $4^{\mathrm{T}} ; 3$, A. aquatilis $\mathrm{A} 8-7^{\mathrm{T}} ; 4$, A. boritolerans $\mathrm{T}-22^{\mathrm{T}} ; 5$, A. mannitolivorans $\mathrm{JC} 2050^{\mathrm{T}} ; 6$, A. olei CC-Hsuan- $617^{\mathrm{T}} ; 7$, A. ratkowskyi $\mathrm{IC} 025^{\mathrm{T}}$. All strains are positive for oxidase, catalase and $\beta$-galactosidase activity, and utilization of D-glucose and lactose. All are non-flagellated, have MK-7 as predominant respiratory quinone, are pink-, orange- or red-pigmented, and do not require $\mathrm{NaCl}$ for growth. All strains are negative concerning gliding motility, fermentation of glucose, urease activity, and presence of flexirubintype pigments. Data for reference strains are from Ahmed et al. (2007), Bowman et al. (2003), Liu et al. (2009), Nedashkovskaya et al. (2007), Tiago et al. (2006), Yi \& Chun (2004) and Young et al. (2009). +, Positive; w, weakly positive; -, negative; v, variable; ND, not determined.

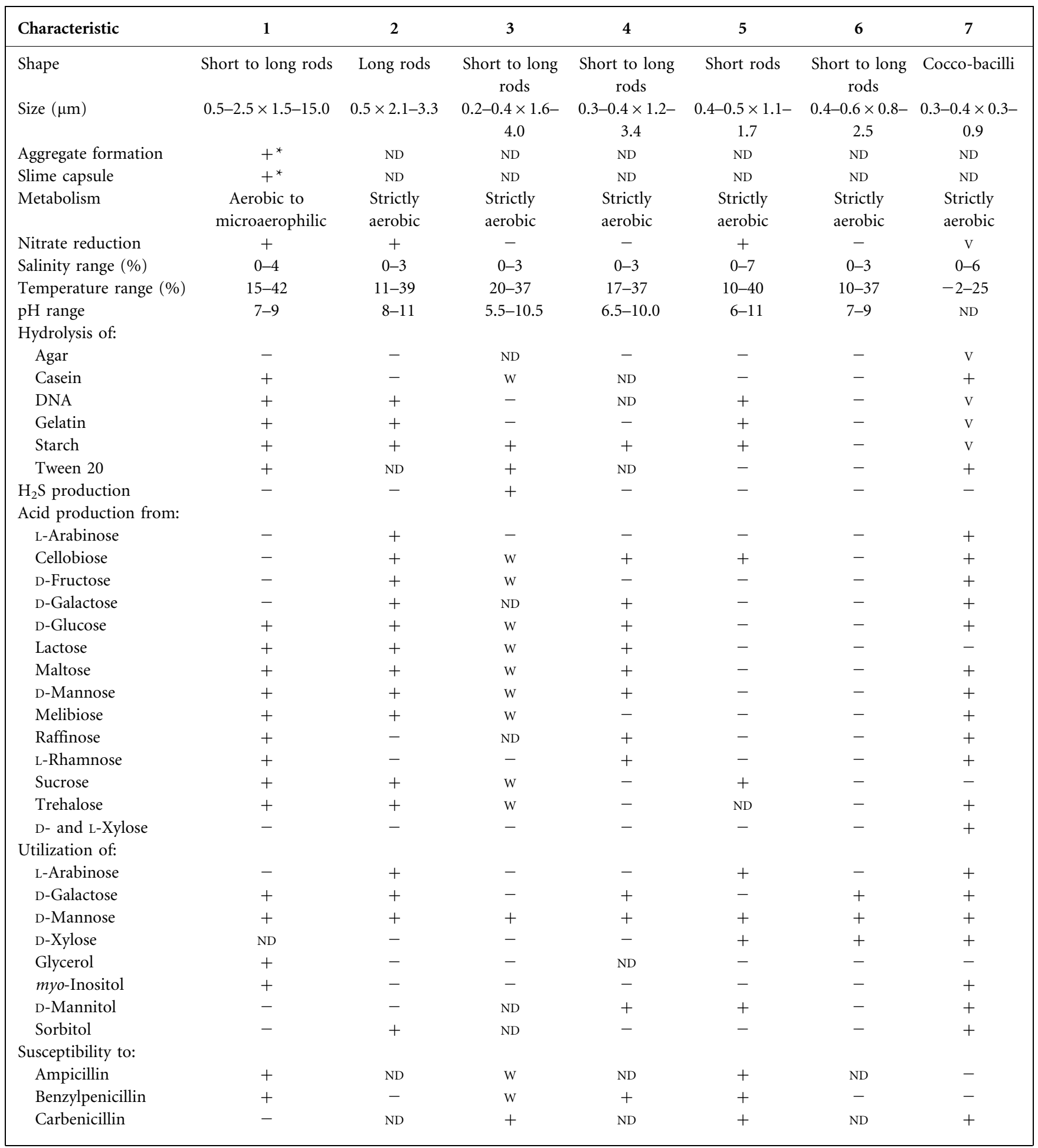


Table 1. cont.

\begin{tabular}{|c|c|c|c|c|c|c|c|}
\hline Kanamycin & - & + & + & - & - & $\mathrm{ND}$ & - \\
\hline Lincomycin & + & $\mathrm{ND}$ & ND & $\mathrm{ND}$ & + & $\mathrm{ND}$ & + \\
\hline Polymyxin B & + & - & + & ND & - & $\mathrm{ND}$ & - \\
\hline Streptomycin & + & - & + & ND & + & $\mathrm{ND}$ & - \\
\hline Tetracycline & + & - & + & + & + & + & + \\
\hline
\end{tabular}

${ }^{*}$ See Supplementary Figure S1.

determined using API $50 \mathrm{CH}$ test strips (bioMérieux) according to the manufacturer's recommendations. Evaluation was performed after two and seven days. The aerobic dissimilation of 95 carbon sources was studied by using the Biolog GN2 MicroPlate system according to the manufacturer's instructions. Antibiotic susceptibility as well as degradation of casein, cellulose (filter paper and CMcellulose), egg yolk, RNA (method 1) and Tween 20 (method 2) were tested according to the appropriate methods as described by Smibert \& Krieg (1994). Hydrolysis of birchwood xylan was determined according to Yoon et al. (2004). Hydrolysis of starch, gelatin, urea and agar was tested as described by Süßmuth et al. (1987) and Nedashkovskaya et al. (2004). The presence of DNase was determined as described by Schreier (1969). The API 10S system (bioMérieux) was used according to the manufacturer's instructions for testing additional enzymic reactions of strain $\mathrm{T} 4^{\mathrm{T}}$. Pigment-absorption spectrum analysis was performed spectrophotometrically (model DU640; Beckman), as described by Yoon et al. (2004). The presence of flexirubin-like pigments was tested by the method of Güde (1980).

Biomass of strain $\mathrm{T}^{\mathrm{T}}$ from a 2-day-old culture, grown in liquid $\mathrm{MSM}^{+}$medium, was taken for the analysis of isoprenoid quinones as well as for determination of DNA $\mathrm{G}+\mathrm{C}$ content, 16S rRNA gene sequence and DNA-DNA hybridization (DDH). Isoprenoid quinones were extracted and analysed as described by Komagata \& Suzuki (1987). For the analyses of cellular fatty acids and polar lipids, strain $\mathrm{T} 4^{\mathrm{T}}$ was grown in marine 2216 medium (Difco) for better comparison with results obtained for other species of the genus Algoriphagus. Cells were harvested at the beginning of the stationary growth phase and lyophilized. Both analyses were carried out by the Identification Service and Dr Brian Tindall, Deutsche Sammlung von Mikroorganismen und Zellkulturen (DSMZ), Braunschweig, Germany. DNA was isolated as described by Marmur (1961). Concentration and purity of the DNA were examined according to the method of Moore et al. (1999). The DNA G + C content (mol\%) was determined using the thermal denaturation method (Marmur \& Doty, 1962) as a mean value of 36 determinations. DDH was carried out between strain $\mathrm{T} 4^{\mathrm{T}}$ and Algoriphagus aquatilis $\mathrm{A} 8-7^{\mathrm{T}}$, the closest relative on the basis of the results of $16 \mathrm{~S}$ rRNA gene sequence analyses. Strains $\mathrm{T} 4^{\mathrm{T}}$ and $A$. aquatilis $\mathrm{A} 8-7^{\mathrm{T}}$ were cultivated in $\mathrm{MSM}^{+}$and $\mathrm{YP}$ medium (Liu et al., 2009), respectively, for DNA isolation before performing DDH. The latter two procedures were performed at the DSMZ according to Cashion et al. (1977), De Ley et al. (1970) and Huss et al. (1983).

Extraction of genomic DNA for 16S rRNA gene sequence determination and PCR were carried out as described by Neilan (1995). PCR products were purified with the Qiagen QIAquick PCR product purification kit according to the manufacturer's instructions, and DNA sequencing was performed by GATC Biotech (Konstanz, Germany). The sequences obtained from amplification were merged together by using Chromas Pro version 1.34 (Technelysium Pty Ltd). The closest relatives of strain $\mathrm{T}^{\mathrm{T}}$ were determined by performing BLAST database searches. Subsequent analyses of the $16 \mathrm{~S}$ rRNA gene sequence of the new isolate, as well as of closely related sequences, were performed using the ARB software package (version RC 5.1 SVN 6289M; Ludwig et al., 2004) and the corresponding SILVA SSURef 104 database (release October 2010; Pruesse et al., 2007). The nearly complete $16 \mathrm{~S}$ rRNA sequence of strain $\mathrm{T}^{\mathrm{T}}$ (1398 bp) was aligned automatically using the PT server implemented in the ARB software package, and the alignment was checked manually. Phylogenetic trees were reconstructed according to the neighbour-joining (Saitou \& Nei, 1987), maximumparsimony (Fitch, 1971) and maximum-likelihood (Felsenstein, 1981) methods. The stability of the groupings was estimated by bootstrap analysis (Felsenstein, 1985) of the neighbour-joining and maximum-parsimony methods based on 1000 replications. As suggested by Tindall et al. (2010), the alignment as well as the exact parameters for the reconstruction of the phylogenetic trees are given in Supplementary Files S1 (a and b) and S2, respectively, available in IJSEM Online.

If not otherwise stated, all tests were performed in duplicate. Cellular fatty acid and polar lipid analyses as well as the $16 \mathrm{~S}$ rRNA gene sequence determination were performed only once.

The main morphological, physiological and biochemical properties of strain $\mathrm{T} 4^{\mathrm{T}}$ are shown in Table 1 or are given in the species description. Table 1 also gives an overview of 
Table 2. Cellular fatty acids (\%) of strain $T 4^{\top}$ and closely related species of the genus Algoriphagus, including $A$. ratkowskyi $\mathrm{ICO} 25^{\top}$, the type species of the genus

Strains: 1, Algoriphagus aquaeductus sp. nov. $\mathrm{T}^{\mathrm{T}}$; 2 , A. alkaliphilus $\mathrm{AC}-$ $74^{\mathrm{T}} ; 3$, A. aquatilis $\mathrm{A} 8-7^{\mathrm{T}} ; 4$, A. boritolerans $\mathrm{T}-22^{\mathrm{T}} ; 5$, A. mannitolivorans JC2050 ${ }^{\mathrm{T}}$; 6, A. olei CC-Hsuan- $617^{\mathrm{T}}$; 7, A. ratkowskyi $\mathrm{IC} 025^{\mathrm{T}}$. Values for predominant fatty acids are in bold type. Data for reference strains are from Ahmed et al. (2007), Bowman et al. (2003), Liu et al. (2009), Tiago et al. (2006), Yi \& Chun (2004) and Young et al. (2009). Predominant fatty acids are in bold type. ECL, Equivalent chain-length; - , not detected/not reported.

\begin{tabular}{|c|c|c|c|c|c|c|c|}
\hline Fatty acid & 1 & 2 & 3 & 4 & 5 & 6 & 7 \\
\hline iso- $\mathrm{C}_{11: 0}$ & - & 0.9 & - & 0.7 & - & 2.1 & - \\
\hline anteiso- $\mathrm{C}_{11: 0}$ & - & 2.6 & - & 1.5 & 1.7 & 0.8 & 2.1 \\
\hline iso- $\mathrm{C}_{13: 0}$ & 0.2 & - & - & - & - & - & - \\
\hline $\begin{array}{l}\text { Unknown ECL } \\
13.565\end{array}$ & - & - & 1.7 & 2.1 & - & - & - \\
\hline $\begin{array}{l}\text { Unknown ECL } \\
13.566\end{array}$ & - & 3.7 & - & - & - & - & - \\
\hline $\begin{array}{l}\text { Unknown ECL } \\
14.959\end{array}$ & - & - & 1.0 & - & - & - & - \\
\hline $\mathrm{C}_{14: 0}$ & 0.6 & - & 1.4 & - & - & - & - \\
\hline iso- $\mathrm{C}_{14: 0}$ & 0.6 & 0.3 & 0.6 & 0.4 & 1.2 & - & 1.4 \\
\hline $\mathrm{C}_{14: 1} \omega 5 c$ & 0.2 & - & - & - & - & - & - \\
\hline $\mathrm{C}_{15: 0}$ & - & 1.6 & 1.2 & 2.6 & 1.7 & 1.4 & 1.6 \\
\hline $\mathrm{C}_{15: 0} 3-\mathrm{OH}$ & - & - & 3.1 & - & - & - & - \\
\hline iso- $\mathrm{C}_{15: 0}$ & 32.2 & 32.4 & 40.3 & 21.3 & 28.7 & 41.0 & 30.5 \\
\hline anteiso- $\mathrm{C}_{15: 0}$ & 4.1 & 3.4 & 4.7 & 7.0 & 4.6 & 1.0 & 3.6 \\
\hline $\mathrm{C}_{15: 0} 2-\mathrm{OH}$ & 0.3 & 0.5 & - & 0.6 & - & - & - \\
\hline iso- $\mathrm{C}_{15: 0} 3-\mathrm{OH}$ & 3.9 & 3.2 & 4.9 & 2.2 & 3.6 & 3.2 & 2.9 \\
\hline iso- $\mathrm{C}_{15: 1} \mathrm{G}$ & 0.6 & 1.4 & 1.9 & 0.5 & 1.0 & 6.9 & 1.1 \\
\hline $\mathrm{C}_{15: 1} \omega 6 c$ & 0.3 & 1.9 & 3.1 & 0.3 & 2.5 & 1.7 & 2.1 \\
\hline $\mathrm{C}_{16: 0}$ & 1.2 & 0.4 & 0.9 & 3.5 & - & - & 2.9 \\
\hline $\mathrm{C}_{16: 0} 3-\mathrm{OH}$ & 2.1 & - & - & - & 0.6 & - & 1.9 \\
\hline iso- $\mathrm{C}_{16: 0}$ & 2.0 & 3.2 & 2.2 & 6.5 & 3.7 & 0.8 & 3.4 \\
\hline iso- $\mathrm{C}_{16: 0} 3-\mathrm{OH}$ & 1.6 & 1.3 & 1.7 & 1.0 & 4.0 & - & 2.8 \\
\hline iso- $\mathrm{C}_{16: 1}$ & - & - & 1.8 & - & - & 0.6 & - \\
\hline iso- $\mathrm{C}_{16: 1} \mathrm{H}$ & 1.2 & 3.8 & - & 3.3 & 2.8 & - & 1.7 \\
\hline $\mathrm{C}_{16: 1} \omega 5 c$ & 5.8 & 1.2 & 2.5 & - & 1.3 & 0.6 & 5.8 \\
\hline $\begin{array}{l}\text { Unknown ECL } \\
16.580\end{array}$ & - & 1.3 & - & - & - & - & - \\
\hline iso- $\mathrm{C}_{17: 0}$ & 0.4 & 0.8 & - & 3.2 & - & - & - \\
\hline $\mathrm{C}_{17: 0} 2-\mathrm{OH}$ & 0.7 & - & - & 2.1 & 0.7 & - & - \\
\hline iso- $\mathrm{C}_{17: 0} 3-\mathrm{OH}$ & 7.9 & 7.4 & 4.0 & 7.5 & 7.9 & 7.2 & 9.2 \\
\hline $\mathrm{C}_{17: 1} \omega 6 c$ & 0.9 & 1.7 & 2.4 & 2.5 & 3.1 & 1.7 & 0.5 \\
\hline iso- $\mathrm{C}_{17: 1} \omega 9 c$ & 7.6 & 14.6 & 6.0 & 13.3 & 5.6 & 11.2 & 1.5 \\
\hline anteiso- $\mathrm{C}_{17: 1} \omega 9 c$ & - & - & - & 1.9 & - & - & - \\
\hline iso- $\mathrm{C}_{19: 1} \mathrm{I}$ & - & - & - & - & - & 0.6 & - \\
\hline \multicolumn{8}{|l|}{ Summed features ${ }^{*}$} \\
\hline 1 & 0.2 & - & - & - & - & - & - \\
\hline 3 & 22.50 & 9.2 & 12.1 & 10.0 & 13.7 & 7.1 & 22.3 \\
\hline 4 & 1.7 & 3.9 & - & 0.4 & 4.8 & 4.3 & 0.9 \\
\hline 8 & 0.7 & - & - & - & - & - & - \\
\hline
\end{tabular}

${ }^{*}$ Summed features consist of one or more fatty acids that cannot be separated by the method used. Summed feature 1 contains iso- $\mathrm{C}_{15: 1}$ $\mathrm{H}$ and/or $\mathrm{C}_{13: 0} 3-\mathrm{OH}$; summed feature 3 contains iso- $\mathrm{C}_{15: 0} 2-\mathrm{OH}$, $\mathrm{C}_{16: 1} \omega 6 c$ and/or $\mathrm{C}_{16: 1} \omega 7 c$; summed feature 4 contains iso- $\mathrm{C}_{17: 1} \mathrm{I}$ and/or anteiso- $C_{17: 1} B$; summed feature 8 contains $C_{18: 1} \omega 7 c$ and/or $\mathrm{C}_{18: 1} \omega 6 c$. differential phenotypic characteristics between strain $\mathrm{T} 4^{\mathrm{T}}$ and closely related species of the genus Algoriphagus, including Algoriphagus ratkowskyi $\mathrm{IC}^{2} 5^{\mathrm{T}}$, the type species of the genus (a comprehensive comparison is shown in Supplementary Table S1).

Best growth was observed on $\mathrm{MSM}^{+}$. When strain $\mathrm{T}^{\mathrm{T}}$ was grown on NA/2 agar, smaller colonies with less intense pigmentation were observed. The isolate seemed to be relatively restricted in its utilization of organic compounds as sole carbon sources, because it preferred mono- and disaccharides, followed by oligo-, polysaccharides, and deoxysugars. However, if alcohols, alditols, amides, amines, carboxylic acids or amino acids were supplied, strain $\mathrm{T} 4^{\mathrm{T}}$ was not able to use most of these carbon sources for growth. Other species of the genus Algoriphagus are also relatively restricted in their utilization of organic compounds as sole carbon sources. Strain $\mathrm{T} 4^{\mathrm{T}}$ could assimilate $\mathrm{D}$-mannitol and myo-inositol, whereas all other members of this genus could not. Strain $\mathrm{T}^{\mathrm{T}}$ produced acids from a broad range of organic compounds. These findings are in accordance with results obtained for other species of the genus Algoriphagus. The statements given above about other members of the genus Algoriphagus are supported by data from Ahmed et al. (2007), Bowman et al. (2003), Copa-Patiño et al. (2008), Liu et al. (2009), Nedashkovskaya et al. (2004, 2007), Park et al. (2010), Tiago et al. (2006), Van Trappen et al. (2004), Yi \& Chun (2004), Yoon et al. (2005a), Yoon et al. (2005b), Yoon et al. (2006), Yoon et al. (2004) and Young et al. (2009).

The overall cellular fatty acid profile of strain $T 4^{\mathrm{T}}$ was mainly the same as those of closely related species of the genus Algoriphagus, with iso- $\mathrm{C}_{15: 0}(32.2 \%)$, summed feature $3\left(\mathrm{C}_{16: 1} \omega 6 c\right.$ and/or $\left.\mathrm{C}_{16: 1} \omega 7 c ; 22.5 \%\right)$ and iso$\mathrm{C}_{17: 0} 3-\mathrm{OH}(7.9 \%)$ as the predominant fatty acids. A comparison of fatty acids of strain $\mathrm{T} 4^{\mathrm{T}}$ with those of closely related species of the genus Algoriphagus, including A. ratkowskyi $\mathrm{IC} 025^{\mathrm{T}}$, the type species of the genus, is given in Table 2 (a more comprehensive comparison is shown in Supplementary Table S2). The polar lipid profile consisted of phosphatidylethanolamine, five unknown phospholipids, three unknown aminophospholipids and three unknown lipids (data not shown).

The nearly complete $16 \mathrm{~S}$ rRNA gene sequence of strain $\mathrm{T} 4^{\mathrm{T}}$ was used for a BLAST search against GenBank. The result clearly indicated that the isolate belongs to the family Cyclobacteriaceae within the CFB group. Sequence similarities between strain $\mathrm{T} 4^{\mathrm{T}}$ and type strains of closely related species of the genus Algoriphagus were 93.3-98.8\%. The highest similarity values obtained for strain $\mathrm{T} 4^{\mathrm{T}}$ and species with validly published names were found with $A$. aquatilis A8- $7^{\mathrm{T}}$ (98.8\%), Algoriphagus olei CC-Hsuan- $617^{\mathrm{T}}$ (98.1\%), Algoriphagus alkaliphilus AC-74 ${ }^{\mathrm{T}}(96.2 \%)$, Algoriphagus mannitolivorans $\mathrm{JC}^{2} 050^{\mathrm{T}}(96.2 \%)$ and Algoriphagus boritolerans $\mathrm{T}-22^{\mathrm{T}}(95 \%)$. To test the genomic uniqueness of a novel isolate, Stackebrandt \& Ebers (2006) recommend a 16S rRNA gene sequence similarity threshold range of 98.7$99.0 \%$ instead of $97.0 \%$ as the point at which DNA-DNA 


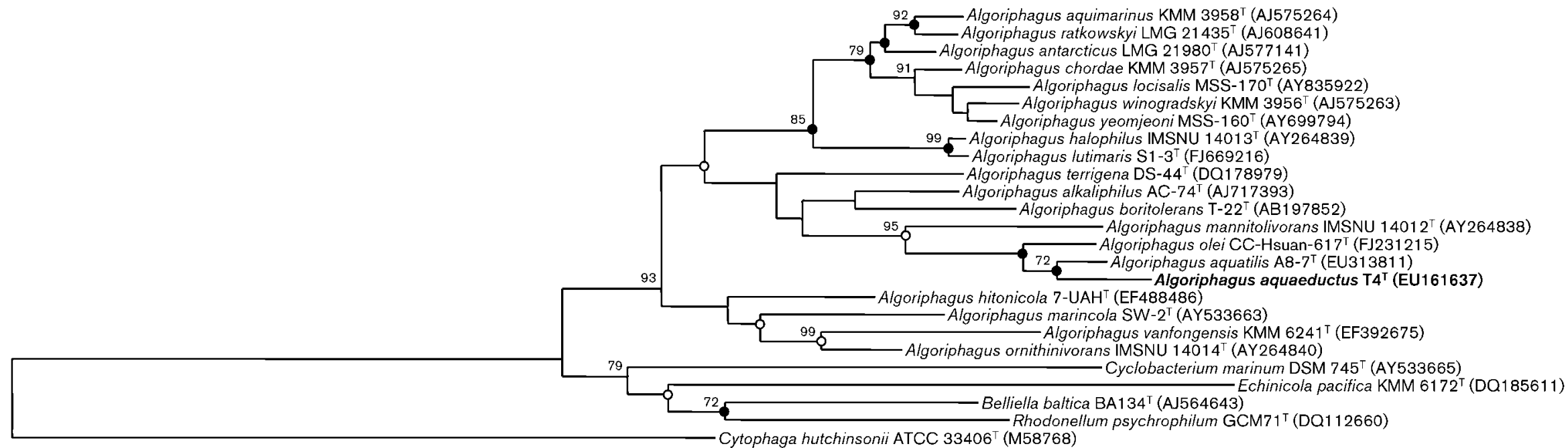
0.10

Fig. 1. Neighbour-joining phylogenetic tree based on $16 \mathrm{~S}$ rRNA gene sequences showing the position of strain $\mathrm{T} 4^{\top}$ in the family $C y c l o b a c t e r i a c e a e . ~ B o o t s t r a p ~ v a l u e s$ ( $>70 \%$ ) based on 1000 resamplings are shown. Filled circles indicate that the corresponding nodes were also recovered in trees generated with the maximum-parsimony and maximum-likelihood algorithms. Open circles indicate that the corresponding nodes were also recovered with either the maximum-parsimony or the maximum-likelihood algorithm. The sequence of Cytophaga hutchinsonii ATCC $33406^{\top}$ (GenBank accession no. M58768) was used as an outgroup. Bar, 0.1 substitutions per nucleotide position. 
hybridization experiments should be obligatory. Therefore, such experiments were performed and showed that strain $\mathrm{T} 4^{\mathrm{T}}$ had less than $37.5 \%$ DNA-DNA relatedness with $A$. aquatilis $\mathrm{A} 8-7^{\mathrm{T}}$. The recommended criteria for delineating bacterial species state that less than $70 \%$ DNA-DNA relatedness (Wayne et al., 1987) indicates that strains belong to separate species. Meanwhile, it is accepted that different genera contain a number of species that share $16 \mathrm{~S}$ rRNA gene sequence similarities of significantly higher than $97 \%$ while sharing DNA-DNA relatedness values well below the $70 \%$ cut-off point recommended for the differentiation of genomic species (Kang et al., 2009; Park et al., 2010; Yassin et al., 2010). Therefore, strain $\mathrm{T}^{\mathrm{T}}$ should be placed as a novel species in the genus Algoriphagus.

The distinctiveness of strain $\mathrm{T} 4^{\mathrm{T}}$ is also documented in the phylogenetic tree (Fig. 1). Strain $\mathrm{T}^{\mathrm{T}}$ clustered with $A$. aquatilis $\mathrm{A} 8-7^{\mathrm{T}}$ (72\% bootstrap support), A. olei CC-Hsuan$617^{\mathrm{T}}$ and A. mannitolivorans $\mathrm{JC} 2050^{\mathrm{T}}$. A sister group to this clade was formed by $A$. alkaliphilus $\mathrm{AC}-74^{\mathrm{T}}$ and $A$. boritolerans $\mathrm{T}-22^{\mathrm{T}}$. The overall tree topology was supported by all tree-making methods used in this study. However, the branching patterns of the species of the genus Algoriphagus varied a little depending on the tree-making method used.

The phylogenetic and genetic distinctiveness of strain $\mathrm{T} 4^{\mathrm{T}}$, combined with differential phenotypic properties, are both enough to show that this strain is apart from other species of the genus Algoriphagus. Thus, on the basis of the phenotypic, chemotaxonomic, phylogenetic and genetic findings, strain $\mathrm{T}^{\mathrm{T}}$ is regarded to represent a novel species of the genus Algoriphagus, for which the name Algoriphagus aquaeductus sp. nov. (type strain $\mathrm{T}^{\mathrm{T}}$ ) is proposed.

\section{Description of Algoriphagus aquaeductus sp. nov.}

Algoriphagus aquaeductus (a.qua.e.duc'tus. L. gen. masc. n. aquaeductus of/from a conduit, a water pipe).

Gram-staining-negative and forms long rod-shaped cells, 0.5$2.5 \times 1.5-15.0 \mu \mathrm{m}$ in size, surrounded by a slime capsule. Cells occur singly, in the form of short chains or in aggregates, are non-spore-forming and non-motile. Aerobic to microaerophilic and chemoheterotrophic. Colonies are circular, umbonate, glistening, non-luminescent, butyraceous, opaque and orange with entire margins. Oxidase- and catalasepositive. Optimum temperature for growth is $25-30{ }^{\circ} \mathrm{C}$; no growth occurs at 10 or $45^{\circ} \mathrm{C}$. Optimum growth at $\mathrm{pH} 8$; no growth occurs at pH 6 or 10. Grows with up to $4 \%(\mathrm{w} / \mathrm{v})$ $\mathrm{NaCl}$, but best growth occurs without $\mathrm{NaCl}$. Can be classified as mesophilic, neutral to alkaliphilic, and halotolerant. Growth under anaerobic conditions is obtained only when medium is supplemented with nitrate. Absorption maxima of carotenoids occur at $478 \mathrm{~nm}$ with shoulders at 449 and $502 \mathrm{~nm}$ (see Supplementary Figure S2). Flexirubin-type pigments are absent. The major respiratory quinone is MK7. Major polar lipids are phosphatidylethanolamine, phospholipids, aminophospholipids and other lipids of unknown character. The predominant fatty acids are iso- $\mathrm{C}_{15: 0}$, summed feature $3\left(\mathrm{C}_{16: 1} \omega 6 c\right.$ and/or $\left.\mathrm{C}_{16: 1} \omega 7 c\right)$ and iso- $\mathrm{C}_{17: 0} 3-\mathrm{OH}$. Casein, DNA, gelatin, starch, RNA and Tween 20 are hydrolysed, but agar, cellulose (filter paper and CMcellulose), egg yolk, urea and xylan are not. $\beta$-Galactosidase is present, whereas lysine decarboxylase, ornithine decarboxylase and tryptophan deaminase are absent. Indole and $\mathrm{H}_{2} \mathrm{~S}$ are not produced. Sensitive to ( $\mu \mathrm{g}$ per disc) ampicillin (10), chloramphenicol (25), lincomycin (15), neomycin (15), penicillin G (15), polymyxin B (30), rifampicin (20), streptomycin (30), tetracycline (20) and novobiocin (20). Tolerant of carbenicillin (25) and kanamycin (30). Assimilates cellobiose, D-fructose, D-galactose, gentiobiose, $\alpha$-D-glucose, $\alpha$-lactose, lactulose, maltose, D-mannose, sucrose, trehalose, turanose, succinic acid monomethyl ester, $\alpha$ cyclodextrin, dextrin, glycogen, myo-inositol, L-asparagine, $N$-acetyl-D-glucosamine and glycerol, but not melibiose, methyl $\beta$-D-glucoside, raffinose, acetic acid, $\alpha$-ketobutyric acid, $\alpha$-ketovaleric acid, propionic acid, L-alaninamide, Lalanine, L-glutamic acid, glycyl L-aspartic acid, L-leucine, Lornithine, L-threonine, $\alpha$-D-glucose 1-phosphate, D-glucose 6-phosphate, Tween 40, Tween 80, L-arabinose, $N$-acetyl-Dgalactosamine, adonitol, D-arabitol, i-erythritol, L-fucose, Dmannitol, D-psicose, L-rhamnose, D-sorbitol, xylitol, pyruvic acid methyl ester, cis-aconitic acid, citric acid, formic acid, Dgalactonic acid lactone, D-galacturonic acid, D-gluconic acid, D-glucosaminic acid, D-glucuronic acid, $\alpha$-hydroxybutyric acid, $\beta$-hydroxybutyric acid, $\gamma$-hydroxybutyric acid, $p$-hydroxyphenylacetic acid, itaconic acid, $\alpha$-ketoglutaric acid, DLlactic acid, malonic acid, quinic acid, D-saccharic acid, sebacic acid, succinic acid, bromosuccinic acid, succinamic acid, glucuronamide, D-alanine, L-alanyl glycine, L-aspartic acid, glycyl L-glutamic acid, L-histidine, hydroxy-L-proline, Lphenylalanine, L-proline, L-pyroglutamic acid, D-serine, Lserine, DL-carnitine, $\gamma$-aminobutyric acid, urocanic acid, inosine, uridine, thymidine, phenylethylamine, putrescine, 2-aminoethanol, 2,3-butanediol or DL- $\alpha$-glycerol phosphate. Acids are produced from D-glucose, D-mannose, lactose, melibiose, maltose, sucrose, trehalose, turanose, gentiobiose, arbutin, aesculin, 5-ketogluconate, raffinose and glycogen, but not from D-arabinose, L-arabinose, D-ribose, L-sorbose, D-lyxose, D-tagatose, D-fructose, D-xylose, L-xylose, cellobiose, D-galactose, $N$-acetyl-D-glucosamine, L-rhamnose, D-fucose, L-fucose, $\beta$-methyl D-xyloside, $\alpha$-methyl D-mannoside, $\alpha$ methyl D-glucoside, amygdalin, salicin, melezitose, amidone, inulin, glycerol, erythritol, D-mannitol, D-sorbitol, xylitol, Darabitol, L-arabitol, D-adonitol, dulcitol, myo-inositol, gluconate or 2-ketogluconate. The $\mathrm{G}+\mathrm{C}$ content of the DNA of the type strain is $41.8 \mathrm{~mol} \%$.

The type strain is $\mathrm{T}^{\mathrm{T}}\left(\mathrm{DSM} 19759^{\mathrm{T}}=\mathrm{LMG} 24398^{\mathrm{T}}\right.$ $=$ NCIMB $14399^{\mathrm{T}}$ ), isolated from water taken from a freshwater pipe on Tenerife island, Spain.

\section{Acknowledgements}

We are grateful to Professor Hans G. Trüper (University Bonn, Germany) for his valuable help with nomenclature. We would like to express our gratitude to Professor Zhi-Pei Liu (Chinese Academy of Sciences, Beijing, China) for kindly supplying A. aquatilis strain A8- $7^{\mathrm{T}}$. 
We thank Mrs Birgit Lübben (University Bremen, Germany) for collecting the water sample and first isolation steps. We also thank Mrs Anke Toltz (University Bremen, Germany) for accomplishing the transmission electron microscopy and Mrs Martina Stickan for her support to improve the English.

\section{References}

Ahmed, I., Yokota, A. \& Fujiwara, T. (2007). Chimaereicella boritolerans sp. nov., a boron-tolerant and alkaliphilic bacterium of the family Flavobacteriaceae isolated from soil. Int J Syst Evol Microbiol 57, 986-992.

Bast, E. (2001). Mikrobiologische Methoden: Eine Einführung in grundlegende Arbeitstechniken, 2nd edn. Heidelberg \& Berlin: Spektrum Akademischer (in German).

Bowman, J. P., Nichols, C. M. \& Gibson, J. A. E. (2003). Algoriphagus ratkowskyi gen. nov., sp. nov., Brumimicrobium glaciale gen. nov., sp. nov., Cryomorpha ignava gen. nov., sp. nov. and Crocinitomix catalasitica gen. nov., sp. nov., novel flavobacteria isolated from various polar habitats. Int J Syst Evol Microbiol 53, 1343-1355.

Cashion, P., Holder-Franklin, M. A., McCully, J. \& Franklin, M. (1977). A rapid method for the base ratio determination of bacterial DNA. Anal Biochem 81, 461-466.

Copa-Patiño, J. L., Arenas, M., Soliveri, J., Sánchez-Porro, C. \& Ventosa, A. (2008). Algoriphagus hitonicola sp. nov., isolated from an athalassohaline lagoon. Int J Syst Evol Microbiol 58, 424-428.

De Ley, J., Cattoir, H. \& Reynaerts, A. (1970). The quantitative measurement of DNA hybridization from renaturation rates. Eur $J$ Biochem 12, 133-142.

Felsenstein, J. (1981). Evolutionary trees from DNA sequences: a maximum likelihood approach. J Mol Evol 17, 368-376.

Felsenstein, J. (1985). Confidence limits on phylogenies: an approach using the bootstrap. Evolution 39, 783-791.

Fitch, W. M. (1971). Toward defining the course of evolution: minimum change for a specific tree topology. Syst Zool 20, 406-416.

Güde, H. (1980). Occurrence of cytophagas in sewage plants. Appl Environ Microbiol 39, 756-763.

Huss, V. A. R., Festl, H. \& Schleifer, K. H. (1983). Studies on the spectrophotometric determination of DNA hybridization from renaturation rates. Syst Appl Microbiol 4, 184-192.

Kang, S.-J., Choi, N.-S., Choi, J.-H., Lee, J.-S., Yoon, J.-H. \& Song, J.-J. (2009). Brevundimonas naejangsanensis sp. nov., a proteolytic bacterium isolated from soil, and reclassification of Mycoplana bullata into the genus Brevundimonas as Brevundimonas bullata comb. nov. Int J Syst Evol Microbiol 59, 3155-3160.

Komagata, K. \& Suzuki, K. (1987). Lipid and cell wall analysis in bacterial systematics. Methods Microbiol 19, 161-207.

Liu, Y., Li, H., Jiang, J. T., Liu, Y. H., Song, X. F., Xu, C. J. \& Liu, Z. P. (2009). Algoriphagus aquatilis sp. nov., isolated from a freshwater lake. Int J Syst Evol Microbiol 59, 1759-1763.

Ludwig, W., Strunk, O., Westram, R., Richter, L., Meier, H., Yadhukumar, Buchner, A., Lai, T., Steppi, S. \& other authors (2004). ARB: a software environment for sequence data. Nucleic Acids Res 32, 1363-1371.

Marmur, J. (1961). A procedure for the isolation of deoxyribonucleic acid from microorganisms. J Mol Biol 3, 208-218.

Marmur, J. \& Doty, P. (1962). Determination of the base composition of deoxyribonucleic acid from its thermal denaturation temperature. J Mol Biol 5, 109-118.

Moore, E. R. B., Arnscheidt, A., Krüger, A., Strömpl, C. \& Mau, M. (1999). Simplified protocols for the preparation of genomic DNA from bacterial cultures. In Molecular Microbial Ecology Manual 1.6.1, pp. 1-15. Edited by A. D. L. Akkermans, J. D. van Elsas \& F. J. de Bruijn. Dordrecht: Kluwer Academic Press.

Nedashkovskaya, O. I., Vancanneyt, M., Van Trappen, S., Vandemeulebroecke, K., Lysenko, A. M., Rohde, M., Falsen, E., Frolova, G. M., Mikhailov, V. V. \& Swings, J. (2004). Description of Algoriphagus aquimarinus sp. nov., Algoriphagus chordae sp. nov. and Algoriphagus winogradskyi sp. nov., from sea water and algae, transfer of Hongiella halophila Yi and Chun 2004 to the genus Algoriphagus as Algoriphagus halophilus comb. nov. and emended descriptions of the genera Algoriphagus Bowman et al. 2003 and Hongiella Yi and Chun 2004. Int J Syst Evol Microbiol 54, 1757-1764.

Nedashkovskaya, O. I., Kim, S. B., Kwon, K. K., Shin, D. S., Luo, X., Kim, S. J. \& Mikhailov, V. V. (2007). Proposal of Algoriphagus vanfongensis sp. nov., transfer of members of the genera Hongiella Yi and Chun 2004 emend. Nedashkovskaya et al. 2004 and Chimaereicella Tiago et al. 2006 to the genus Algoriphagus, and emended description of the genus Algoriphagus Bowman et al. 2003 emend. Nedashkovskaya et al. 2004. Int J Syst Evol Microbiol 57, 1988-1994.

Neilan, B. A. (1995). Identification and phylogenetic analysis of toxigenic cyanobacteria by multiplex randomly amplified polymorphic DNA PCR. Appl Environ Microbiol 61, 2286-2291.

Park, S., Kang, S.-J., Oh, K.-H., Oh, T.-K. \& Yoon, J.-H. (2010). Algoriphagus lutimaris sp. nov., isolated from a tidal flat sediment. Int J Syst Evol Microbiol 60, 200-204.

Pate, J. L. \& Ordal, E. J. (1967). The fine structure of Chondrococcus columnaris. 3. The surface layers of Chondrococcus columnaris. J Cell Biol 35, 37-51.

Pruesse, E., Quast, C., Knittel, K., Fuchs, B. M., Ludwig, W., Peplies, J. \& Glöckner, F. O. (2007). SILVA: a comprehensive online resource for quality checked and aligned ribosomal RNA sequence data compatible with ARB. Nucleic Acids Res 35, 7188-7196.

Saitou, N. \& Nei, M. (1987). The neighbor-joining method: a new method for reconstructing phylogenetic trees. Mol Biol Evol 4, 406-425.

Schreier, J. B. (1969). Modification of deoxyribonuclease test medium for rapid identification of Serratia marcescens. Am J Clin Pathol 51, 711-716.

Smibert, R. M. \& Krieg, N. R. (1994). Phenotypic Characterization. In Methods for General and Molecular Bacteriology, pp. 607-654. Edited by P. Gerhardt, R. G. E. Murray, W. A. Wood \& N. R. Krieg. Washington, DC: American Society for Microbiology.

Stackebrandt, E. \& Ebers, J. (2006). Taxonomic parameters revisited: tarnished gold standards. Microbiol Today 33, 152-155.

Süßmuth, R., Eberspächer, J., Haag, R. \& Springer, W. (1987). Biochemisch-mikrobiologisches Praktikum. Stuttgart: Thieme.

Tiago, I., Mendes, V., Pires, C., Morais, P. V. \& Veríssimo, A. (2006). Chimaereicella alkaliphila gen. nov., sp. nov., a Gram-negative alkaliphilic bacterium isolated from a nonsaline alkaline groundwater. Syst Appl Microbiol 29, 100-108.

Tindall, B. J., Rosselló-Móra, R., Busse, H.-J., Ludwig, W. \& Kämpfer, P. (2010). Notes on the characterization of prokaryote strains for taxonomic purposes. Int J Syst Evol Microbiol 60, 249-266.

Van Trappen, S., Vandecandelaere, I., Mergaert, J. \& Swings, J. (2004). Algoriphagus antarcticus sp. nov., a novel psychrophile from microbial mats in Antarctic lakes. Int J Syst Evol Microbiol 54, 1969-1973.

Wayne, L. G., Brenner, D. J., Colwell, R. R., Grimont, P. A. D., Kandler, O., Krichevsky, M. I., Moore, L. H., Moore, W. E. C., Murray, R. G. E. \& other authors (1987). Report of the ad hoc committee on reconciliation of approaches of bacterial systematics. Int J Syst Bacteriol 37, 463-464.

Yassin, A. F., Hupfer, H., Siering, C. \& Busse, H.-J. (2010). Chryseobacterium treverense sp. nov., isolated from a human clinical source. Int J Syst Evol Microbiol 60, 1993-1998. 
Yi, H. \& Chun, J. (2004). Hongiella mannitolivorans gen. nov., sp. nov., Hongiella halophila sp. nov. and Hongiella ornithinivorans sp. nov., isolated from tidal flat sediment. Int J Syst Evol Microbiol 54, 157-162.

Yoon, J.-H., Yeo, S.-H. \& Oh, T.-K. (2004). Hongiella marincola sp. nov., isolated from sea water of the East Sea in Korea. Int J Syst Evol Microbiol 54, 1845-1848.

Yoon, J.-H., Kang, S.-J., Jung, S.-Y., Lee, C.-H. \& Oh, T.-K. (2005a). Algoriphagus yeomjeoni sp. nov., isolated from a marine solar saltern in the Yellow Sea, Korea. Int J Syst Evol Microbiol 55, 865-870.
Yoon, J.-H., Kang, S.-J. \& Oh, T.-K. (2005b). Algoriphagus locisalis sp. nov., isolated from a marine solar saltern. Int J Syst Evol Microbiol 55, 1635-1639.

Yoon, J.-H., Lee, M.-H., Kang, S.-J. \& Oh, T.-K. (2006). Algoriphagus terrigena sp. nov., isolated from soil. Int J Syst Evol Microbiol 56, 777-780.

Young, C.-C., Lin, S.-Y., Arun, A. B., Shen, F.-T., Chen, W.-M., Rekha, P. D., Langer, S., Busse, H.-J., Wu, Y.-H. \& Kämpfer, P. (2009). Algoriphagus olei sp. nov., isolated from oil-contaminated soil. Int $J$ Syst Evol Microbiol 59, 2909-2915. 